\title{
KEBERMANFAATAN PENGGUNAAN GEOGEBRA DALAM PEMBELAJARAN MATEMATIKA
}

\author{
Joko Purnomo \\ PPPPTK Matematika, Sleman, D.I.Yogyakarta; mashjoko08@gmail.com
}

\begin{abstract}
Abstrak. Penggunaan Teknologi Informasi dan Komunikasi (TIK) dalam berbagai kegiatan pendidikan menciptakan berbagai kemudahan, meningkatkan efektivitas dan meningkatkan efisiensi. Penggunaan TIK dalam proses pendidikan diyakini akan membuat pembelajaran menjadi lebih menarik, dapat menjelaskan konsep dengan lebih jelas, menumbuhkan kreativitas, keterampilan kolaboratif dan banyak lagi. Karena siswa saat ini adalah generasi milenial yang sangat dekat dengan TIK dalam kehidupan sehari-hari, maka penggunaan TIK menjadi penting. Saat mempelajari matematika, GeoGebra yang merupakan salah satu perangkat lunak open source dinamis, dapat dimanfaatkan sebagai media dalam pembelajaran matematika. Namun, banyak yang masih belum mengetahui manfaat menggunakan GeoGebra untuk pembelajaran matematika. Artikel ini membahas berbagai manfaat penggunaan GeoGebra dalam pembelajaran matematika, dengan beberapa penelitian yang mendukungnya. Kebermanfaatan penggunaan GeoGebra dalam pembelajaran matematika dapat diuraikan sebagai berikut: GeoGebra dapat digunakan untuk mendemonstrasikan atau memvisualisasikan konsep-konsep matematika, sekaligus sebagai sarana mengkonstruksi konsep-konsep matematika. Penggunaan GeoGebra dalam pembelajaran matematika dapat menumbuhkan penalaran matematis, menumbuhkan kreativitas, mendukung kolaborasi, lebih melibatkan siswa dalam proses pembelajaran dan semakin banyak indera yang ikut terlibat, pembelajaran dapat menjadi efektif dan efisien.
\end{abstract}

Kata Kunci. Teknologi Informasi dan Komunikasi (TIK), GeoGebra, Pembelajaran matematika.

\section{The Benefits of Using Geogebra in Mathematics Learning}

\begin{abstract}
The use of Information and Communication Technologies (ICT) in a variety of educational activities creates lots of conveniences, increases effectiveness and efficiency. It is believed that the use of ICT in the educational process makes learning more interesting, enables explaining the concept more clearly, foster creativity, collaborative skills and many more. Due to the fact that the students are millennial generation, who is quite familiar with ICT in their daily life, the use of ICT is important. In learning mathematics, GeoGebra which is dynamic open source software can be used as a teaching and learning tool for mathematics. However, some are still unaware of the benefits of using GeoGebra to learn mathematics. This article discusses the various benefits of using GeoGebra in mathematics teaching and learning, and several studies that support it. The advantages of using GeoGebra in mathematics teaching and learning are as follows: GeoGebra might be used to demonstrate or visualize mathematical concepts, as well as a means of constructing mathematical concepts. The use of GeoGebra in mathematics learning can foster mathematical reasoning, creativity, support collaboration, involve students more in the learning process. And, the more involved, more effective and efficient the learning is.
\end{abstract}

Keyword. Information and Communication Technology (ICT), GeoGebra, Mathematics learning 


\section{Pendahuluan}

Teknologi banyak digunakan dalam berbagai aktivitas yang berhubungan dengan pembelajaran, yaitu untuk memberikan efisiensi dan efektivitas yang lebih besar dalam proses pembelajaran. Perkembangan berbagai ilmu pengetahuan, teknologi dan informasi dewasa ini, menjadikan kebutuhan akan kemampuan guru dalam penguasaan Teknologi Informasi dan Komunikasi (TIK) dalam pembelajaran. Penggunaan TIK dalam pembelajaran ini sesuai dengan kebijakan pemerintah, diantaranya yang terdapat dalam Peraturan Menteri Pendidikan dan Kebudayaan tahun 2016 no. 022 tentang Standar Proses Pendidikan Dasar dan Menengah yang menyatakan bahwa: Sesuai dengan Standar Kompetensi Lulusan dan Standar Isi maka prinsip pembelajaran yang digunakan, salah satunya adalah Pemanfaatan teknologi informasi dan komunikasi untuk meningkatkan efisiensi dan efektivitas pembelajaran. (Baswedan, 2016).

Penggunaan TIK untuk meningkatkan efisiensi dan efektivitas pembelajaran dapat diuraikan sebagai berikut. Penggunaan TIK diyakini akan membuat pembelajaran lebih menarik, dapat menjelaskan konsep dengan lebih jelas, dan lain sebagainya. Penggunaan teknologi informasi dan komunikasi sangat penting mengingat siswa saat ini merupakan generasi milenial yang sangat dekat dengan TIK dalam kehidupan sehari-hari. Oleh karena itu, penting bagi guru untuk dapat memanfaatkannya semaksimal mungkin dalam pembelajaran, sehingga penguasaan TIK untuk pembelajaran menjadi kebutuhan para guru.

Pentingnya TIK dalam pembelajaran, antara lain dalam pembelajaran berbantuan komputer yang disampaikan oleh beberapa praktisi berikut. Pembelajaran berbantuan komputer sangat penting bagi guru dan siswa. Pembelajaran berbantuan komputer penting bagi guru, diantaranya karena: (1) guru lebih banyak berperan sebagai fasilitator siswa, (2) memberikan lebih banyak alternatif perubahan variasi metode pembelajaran, dan (3) meminimalkan tingkat kesalahpahaman konsep/teori yang sering dihadapi siswa sehingga efisiensi dan efektivitas pembelajaran dapat tercapai. Bagi siswa, pembelajaran berbantuan komputer penting karena: (1) siswa lebih mudah dan cepat memahami materi pembelajaran abstrak karena konsep/teori abstrak disajikan dengan cermat dan jelas sehingga siswa lebih mudah dan cepat memahami materi pembelajaran abstrak, (2) meningkatkan motivasi siswa dalam proses pembelajaran, (3) meningkatkan hasil belajar siswa, dan (4) dapat mengakomodasi siswa yang lambat, sehingga dapat menciptakan iklim efektif secara individu (Harini \& I Gede Santi Astawa, 2015).

Pembelajaran berbantuan komputer memiliki manfaat, diantaranya: (1) dapat mengatasi kelemahan-kelemahan pada pembelajaran, (2) merupakan media penyampaian pembelajaran yang efektif, (3) mampu memberikan informasi tentang kesalahan, (4) melatih siswa untuk terampil memilih bagian-bagian isi pembelajaran yang dikehendaki (Padmanthara, 2004). 
Disisi lain, terjadi berbagai permasalahan yang dialami dalam pembelajaran matematika diantaranya adalah: bagaimana menjadikan pembelajaran lebih menarik, bagaimana guru dapat menjelaskan konsep dengan lebih jelas, bagaimana menumbuhkan kreativitas melalui pembelajaran, bagaimana menumbuhkan keterampilan kolaboratif dan lain-lain. Beberapa hal berikut memberikan gambaran adanya berbagai permasalahan yang dihadapi dalam pembelajaran matematika. Wawancara dengan beberapa guru matematika yang dilakukan, ditemukan bahwa pelajaran matematika yang menjelaskan lebih banyak rumus membuat guru lebih mudah menjelaskan konsep matematika dengan menggunakan metode manual, sehingga tidak terlalu memperhatikan pengembangan TIK. Hal ini disebabkan tidak hanya karena sulitnya menuliskan dan menggambarkan konsep matematika di media komputer, tetapi juga karena sulitnya memperoleh perangkat lunak yang tidak menyulitkan proses instalasi (Harini \& I Gede Santi Astawa, 2015).

Penelitian lain menyebutkan bahwa masih banyak guru yang belum tahu memanfaatkan TIK dalam pembelajaran, diantaranya penggunaan GeoGebra dalam pembelajaran matematika. Hal ini tergambarkan diantaranya oleh penelitian yang telah dilakukan oleh Koswara, W., \& Rosita (2017) yang menyampaikan bahwa permasalahan dalam mengimplementasikan proses pembelajaran berbasis teknologi adalah kurangnya kapasitas guru dalam mengoptimalkan teknologi, termasuk pentingnya penggunaan GeoGebra dalam proses pembelajaran serta kurangnya informasi pentingnya pemanfaatan software pembelajaran yang dapat mengkonstruksi konsep-konsep penting dalam matematika.

Berbagai permasalahan pembelajaran matematika tersebut di atas mestinya tidak akan terjadi apabila para guru mempunyai pengetahuan yang memadai mengenai penggunaan TIK dalam pembelajaran matematika. Salah satu pengetahuan dan keterampilan penggunaan TIK yang perlu dimiliki guru adalah pemanfaatan GeoGebra dalam pembelajaran matematika. Sebenarnya banyak software yang dapat dimanfaatkan dalam pembelajaran matematika, seperti: PowerPoint, matlab, maple, GeoGebra dan lain-lain. GeoGebra mempunyai berbagai keunggulan, diantaranya merupakan salah satu software yang bersifat open source, dan bersifat dinamis untuk membuat media pembelajaran matematika (Dikovic, 2009; Hohenwarter et al., 2009). Sifat dinamis dari GeoGebra akan memudahkan peserta didik berinteraksi dengan media yang dibuat dengan GeoGebra, sehingga pada kesempatan ini penulis tertarik untuk membahas kebermanfaatan penggunaan GeoGebra dalam pembelajaran matematika.

GeoGebra diyakini dapat dimanfaatkan dalam pembelajaran matematika dalam rangka mengoptimalkan proses pembelajaran, dimana nantinya diharapkan pembelajaran dapat menjadi lebih menyenangkan, lebih bermakna, dapat memberikan pengalaman belajar yang lebih kepada peserta didik, yang pada akhirnya dapat meningkatkan prestasi belajar. Bagaimana kebermanfaatan penggunaan GeoGebra dalam pembelajaran matematika? Berbagai potensi GeoGebra dalam pembelajaran matematika akan dibahas dalam artikel ini, untuk memberikan gambaran yang lebih nyata dengan mengulasnya dari berbagai penelitian yang mendukung hal tersebut. 
Artikel ini diharapkan dapat memberikan wawasan kepada para pembaca tentang kebermanfaatan penggunaan GeoGebra dalam pembelajaran matematika, dimana selama ini masih banyak yang belum mengetahuinya.

\section{Pembahasan}

\subsection{Pembelajaran matematika}

Matematika memiliki beberapa peranan penting dalam kehidupan manusia, diantaranya dalam menghadapi masalah kehidupan sehari-hari, berpikir kritis maupun untuk melatih logika berpikir. Sholihah \& Mahmudi (2015) mengungkapkan bahwa salah satu bidang studi yang mempunyai peranan penting dalam pendidikan dan masalah kehidupan sehari-hari adalah matematika, dimana matematika dapat memberikan jawaban terhadap permasalahan keseharian.

Standar kemampuan matematika yang perlu dimiliki siswa sebagaimana tercantum dalam standar proses yang dirumuskan oleh NCTM (National Council of Teacher of Mathematics) (2000) yaitu: (1) belajar untuk memecahkan masalah (mathematical problem solving), (2) belajar untuk penalaran dan pembuktian (mathematical reasoning and proof), (3) belajar untuk berkomunikasi (mathematical comminication), (4) belajar untuk mengaitkan ide (mathematical connections), (5) belajar untuk merepresentasikan (mathematical representation) (NCTM, 2000). Dengan demikian pembelajaran matematika seharusnya dapat mencapai standar proses yang dirumuskan oleh NCTM tersebut.

Pembelajaran matematika akan efektif jika siswa yang terlibat langsung dalam mencari, mengerjakan, dan menemukan sendiri pemecahan masalah matematika. Hal ini sejalan dengan motto "Saya mendengar dan saya lupa; saya melihat dan saya ingat; saya tidak mengerti dan saya mengerti." Penting untuk diingat bahwa siswa hendaknya dipilihkan metode dan media pembelajaran yang mendorong mereka aktif dalam setiap kegiatan belajar mengajar. Media pembelajaran didefinisikan sebagai alat bantu yang digunakan dalam kegiatan belajar mengajar dengan tujuan untuk menyampaikan pesan pembelajaran kepada siswa (Harini \& I Gede Santi Astawa, 2015).

Pembelajaran matematika dapat menumbuhkan kecakapan-kecakapan hidup sebagaimana tertuang dalam Permendikbud nomor 21 tahun 2016 tentang standar isi diantaranya adalah (1) menggunakan kemampuan berpikir dan bernalar dalam pemecahan masalah, (2) mengkomunikasikan gagasan secara efektif, (3) memiliki sikap dan perilaku yang sesuai dengan nilai-nilai matematika, seperti taat asas, disiplin, konsisten, menghargai perbedaan pendapat, teliti, tangguh, kreatif, dan terbuka.

Tujuan pembelajaran matematika sebagaimana disampaikan oleh Wardhani (2010) adalah sebagai berikut:

"(1) memahami konsep matematika, menjelaskan keterkaitan antarkonsep dan mengaplikasikan konsep atau algoritma, secara luwes, akurat, efisien, dan tepat 
dalam pemecahan masalah. (2). menggunakan cara berpikir dan bernalar pada pola dan sifat, melakukan manipulasi matematika dalam membuat generalisasi, menyusun bukti, atau menjelaskan gagasan dan pernyataan matematika (3). memecahkan masalah yang meliputi kemampuan memahami masalah, merancang model matematika, menyelesaikan model dan menafsirkan solusi yang diperoleh. (4). mengomunikasikan gagasan dengan simbol, tabel, diagram, atau media lain untuk memperjelas keadaan atau masalah."

Pembelajaran matematika di sekolah tidak hanya bertujuan untuk membantu siswa memahami muatan keilmuan matematika, tetapi juga untuk mendukung pencapaian insan dengan kecakapan abad ke-21. Sebagaimana disampaikan oleh Sumaryanta \& Wibawa (2020) bahwa pembelajaran matematika juga bertujuan untuk memiliki kecakapan abad 21 diantaranya memiliki keterampilan hidup dan karier; keterampilan belajar dan inovatif; keterampilan informasi, media dan teknologi; serta keterampilan kritis, komunikasi, kolaborasi, dan kreativitas yang merupakan keterampilan penting bagi peserta didik untuk siap mengelola kehidupan di era Revolusi Industri 4.0 yang sering disebut sebagai - 4C (critical thinking, communication, collaborative, creativity).

Dari berbagai uraian tentang pembelajaran matematika di atas maka dapat disampaikan bahwa pada pembelajaran matematika tidak hanya fokus pada membelajarkan konten matematika itu sendiri. Pembelajaran matematika hendaknya juga mendukung melatih cara berpikir dan bernalar dalam menarik kesimpulan; mengembangkan kreativitas; mengembangkan kemampuan pemecahan masalah; dan mengembangkan kemampuan mengkomunikasikan gagasan, atau yang dikenal juga sebagai 4C (critical thinking, communication, collaborative, creativity). Disamping itu pembelajaran matematika juga harus menumbuhkan sikap dan perilaku yang sesuai dengan nilai-nilai matematika, seperti taat asas, disiplin, konsisten, menghargai perberbedaan pendapat, teliti, tangguh, dan sebagainya.

\subsection{Penggunaan TIK dalam pembelajaran matematika}

Terdapat berbagai cara untuk mencapai apa yang diharapkan terhadap pembelajaran matematika. Salah satu cara yang dapat dilakukan guru untuk mencapai apa yang diharapkan adalah dengan menggunakan TIK dalam pembelajarannya. Hal ini sejalan dengan yang disampaikan oleh Sumaryanta \& Wibawa (2020), bahwa pembelajaran matematika harus mampu mengambil manfaat sebesar-besarnya pada perkembangan teknologi untuk menunjang keberhasilan pendidikan matematika. Penggunaan teknologi dalam pembelajaran matematika juga dapat memberikan dampak positif terhadap kemampuan penalaran, komunikasi matematis, pemecahan masalah, dan koneksi matematis peserta didik (Rahmawati, 2018:381).

Penggunaan teknologi informasi untuk pembelajaran matematika dibedakan menjadi tiga fungsi, yaitu: (1) Alat belajar mandiri. Alat belajar mandiri termasuk CD interaktif. Guru dapat menggunakan CD interaktif sehingga siswa dapat berinteraksi dengan program yang tersedia pada CD tersebut. (2) Alat bantu pembelajaran. Penggunaan teknologi informasi untuk alat bantu pembelajaran, khususnya program komputer untuk pembelajaran. (3) Sumber pembelajaran. Teknologi informasi berhubungan 
dengan sumber belajar (learning resources) dengan segala komponennya di Internet. Internet dapat dianggap sebagai sumber informasi yang canggih (Supianti, 2018)

TIK telah mengubah peradaban manusia secara signifikan dan dampaknya akan terus meningkat di masa depan, yang harus digunakan secara positif untuk mempelajari matematika. Selain itu, terdapat banyak aplikasi yang kini sangat berguna dalam pembelajaran matematika, seperti geogebra, google-class, quiziz, desmos, matematika simbolik, dan lainnya. Ketersediaan berbagai aplikasi ini memberikan peluang besar bagi guru untuk mengelola pembelajaran matematika di kelas dengan cara yang lebih efisien, efektif, menyenangkan, dan memberdayakan (Sumaryanta \& Wibawa, 2020).

Penggunaan berbagai produk teknologi berguna tidak hanya untuk memberikan hasil dan proses pembelajaran yang optimal, tetapi juga untuk membuat siswa terbiasa dengan teknologi tersebut (Rahmawati, 2018). Pemanfaatan teknologi dalam pembelajaran matematika sekaligus menjadi wahana bagi peserta didik mengetahui dan merasakan keberadaan teknologi, sehingga mereka semakin welcome dan aware terhadap keberadaan dan kebermanfaatan teknologi.

Berdasarkan uraian di atas dapat kita tarik benang merah bahwa penggunaan TIK dalam pembelajaran matematika adalah untuk menunjang keberhasilan pendidikan matematika. Dimana fungsi TIK dalam pembelajaran matematika dapat dibedakan menjadi 3 yaitu: sebagai alat belajar mandiri; alat bantu pembelajaran; dan sumber pembelajaran. Penggunaan TIK dalam pembelajaran matematika akan dapat meningkatkan kemampuan penalaran, komunikasi matematis, dan juga kemampuan pemecahan masalah. Ketersediaan TIK akan dapat membantu guru mengelola pembelajaran matematika menjadi lebih efektif, efisien, menyenangkan, dan memberdayakan. Disamping itu penggunaan TIK akan membuat siswa terbiasa menggunakan teknologi tersebut, dimana secara tidak langsung penggunaan TIK tersebut merupakan salah satu cara untuk membelajarkan TIK kepada siswa.

\subsection{Mengenal software GeoGebra}

Salah satu penggunaan TIK yang perlu diketahui guru untuk membelajarkan matematika adalah GeoGebra. Hal ini karena GeoGebra memiliki berbagai kelebihan yang dapat dimanfaatkan untuk pembelajaran matematika namun belum banyak diketahui oleh para guru. Oleh karena itu, pada bagian ini akan diberikan wawasan mengenai apa Geogebra, cara untuk mendapatkan software geogebra dan spesifikasi dari sofware GeoGebra.

Geogebra singkatan dari Geometry and Algebra, secara umum GeoGebra merupakan program komputer untuk membelajarkan matematika khususnya geometri, aljabar serta kalkulus yang dapat digunakan untuk belajar mengajar di tingkat SD, SMP, SMA, dan Universitas (Hohenwarter \& Hohenwarter, 2008). GeoGebra menawarkan kesempatan bagi guru untuk mengkreasi lingkungan belajar online interaktif yang memungkinkan peserta didik mengeksplorasi berbagai konsep-konsep matematika (Hohenwarter \& Hohenwarter, 2008). GeoGebra membantu peserta didik memperoleh pemahaman yang lebih baik terhadap matematika (Hohenwarter et al., 2007). Program 
ini dapat digunakan dengan bebas (tidak berbayar) dan dapat diunduh dari https://www.geogebra.org.

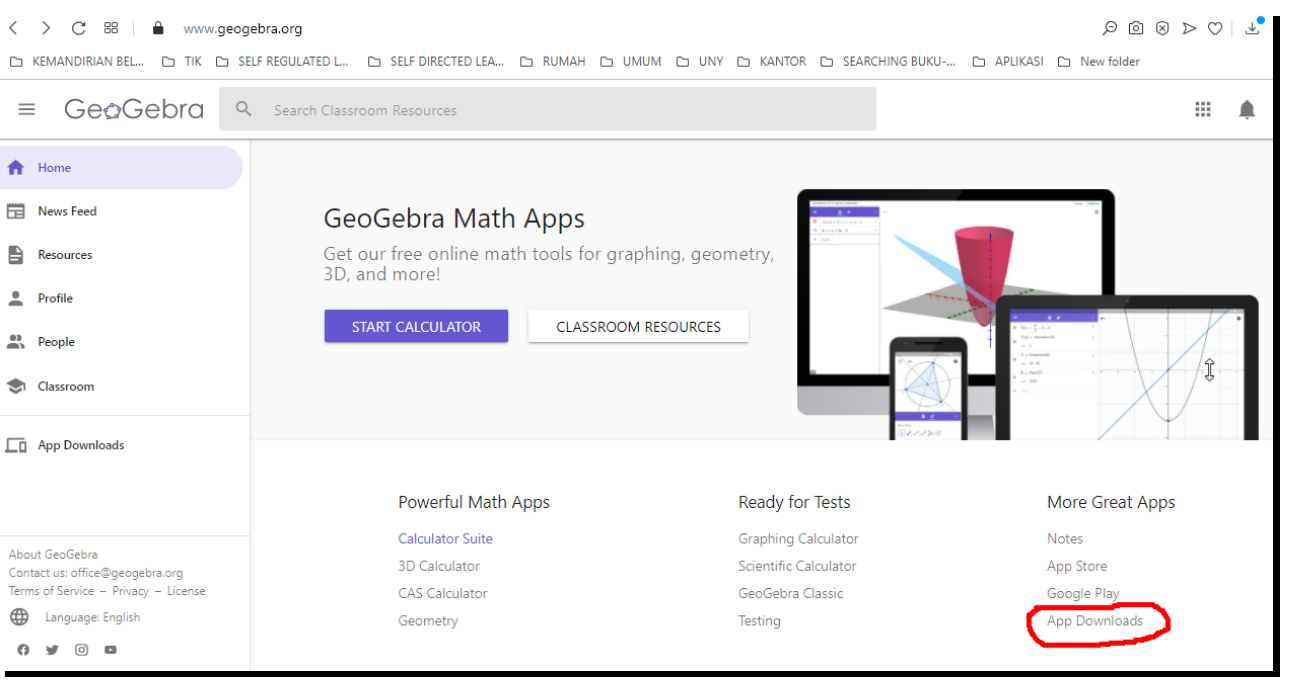

Gambar 1. Situs web GeoGebra

Pada web https://www.geogebra.org dapat didownload software GeoGebra dengan cara klik App download sehingga tampilan web akan berubah seperti gambar 2 . Selanjutnya GeoGebra dapat didownload dalam berbagai versi yang ada, yaitu GeoGebra Classic 5, GeoGebra Classic 6 dan juga beberapa GeoGebra Apps. Khusus untuk GeoGebra Classic 5 harus di download terlebih dahulu kemudian di install, baru setelah itu dapat digunakan. Sedangkan yang lainnya dapat langsung dijalankan secara online dengan cara klik START, atau dapat juga di download kemudian diinstall untuk selanjutnya digunakan secara offline sebagaimana GeoGebra Classic 5.

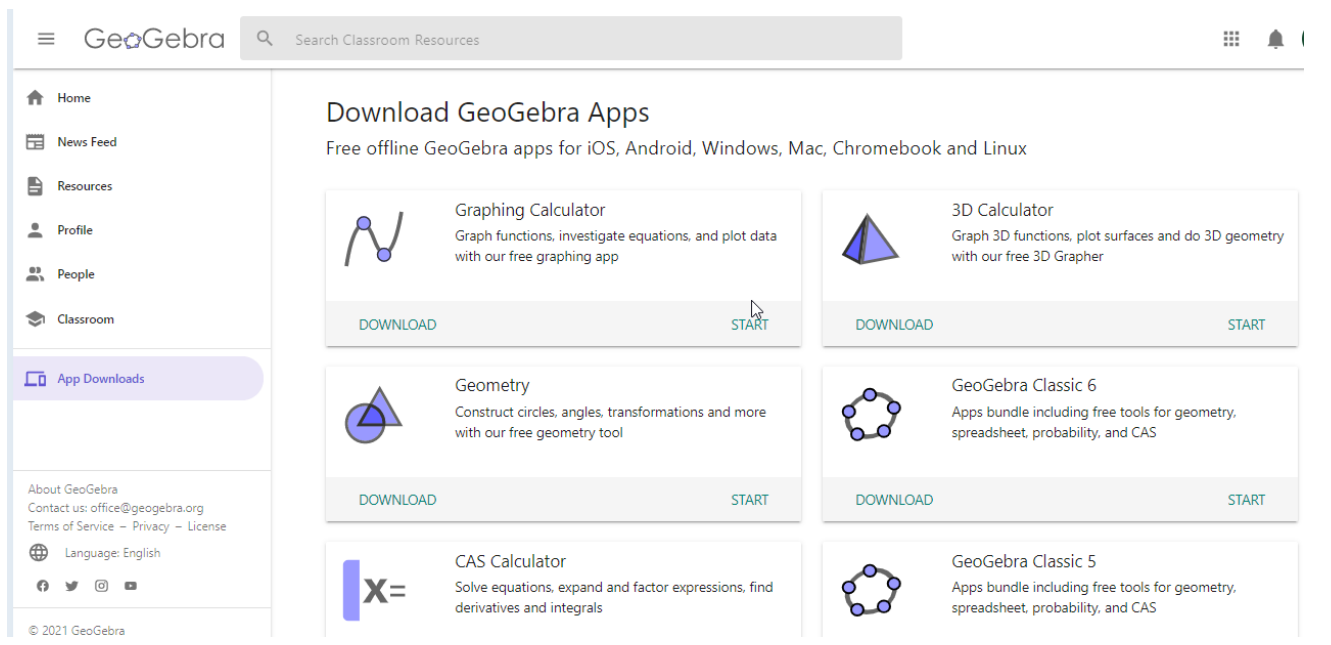

Gambar 2. Download GeoGebra 
Geogebra telah mempunyai banyak versi dan terus mengalami pengembangan. Penemu dan perancangnya terus berusaha memperbaiki dan menambahi kekurangan dari program GeoGebra ini. Pada saat ini telah muncul Geogebra 6 yang sangat mendukung untuk pembelajaran online. Sedangkan GeoGebra 5 sebagai perbaikan dari Geogebra 4.4. Pada Geogebra 4.4 belum ada fasilitas untuk menggambar 3 dimensi, sedangkan GeoGebra 5 telah dapat dijumpai fasilitas untuk menggambar dalam bentuk 3 dimensi.

Tampilan GeoGebra secara umum ditunjukkan oleh Gambar 3 berikut. (pada gambar ini menggunakan GeoGebra 5). Secara garis besar bagian-bagian dari software GeoGebra, dapat dijelaskan sebagai berikut.

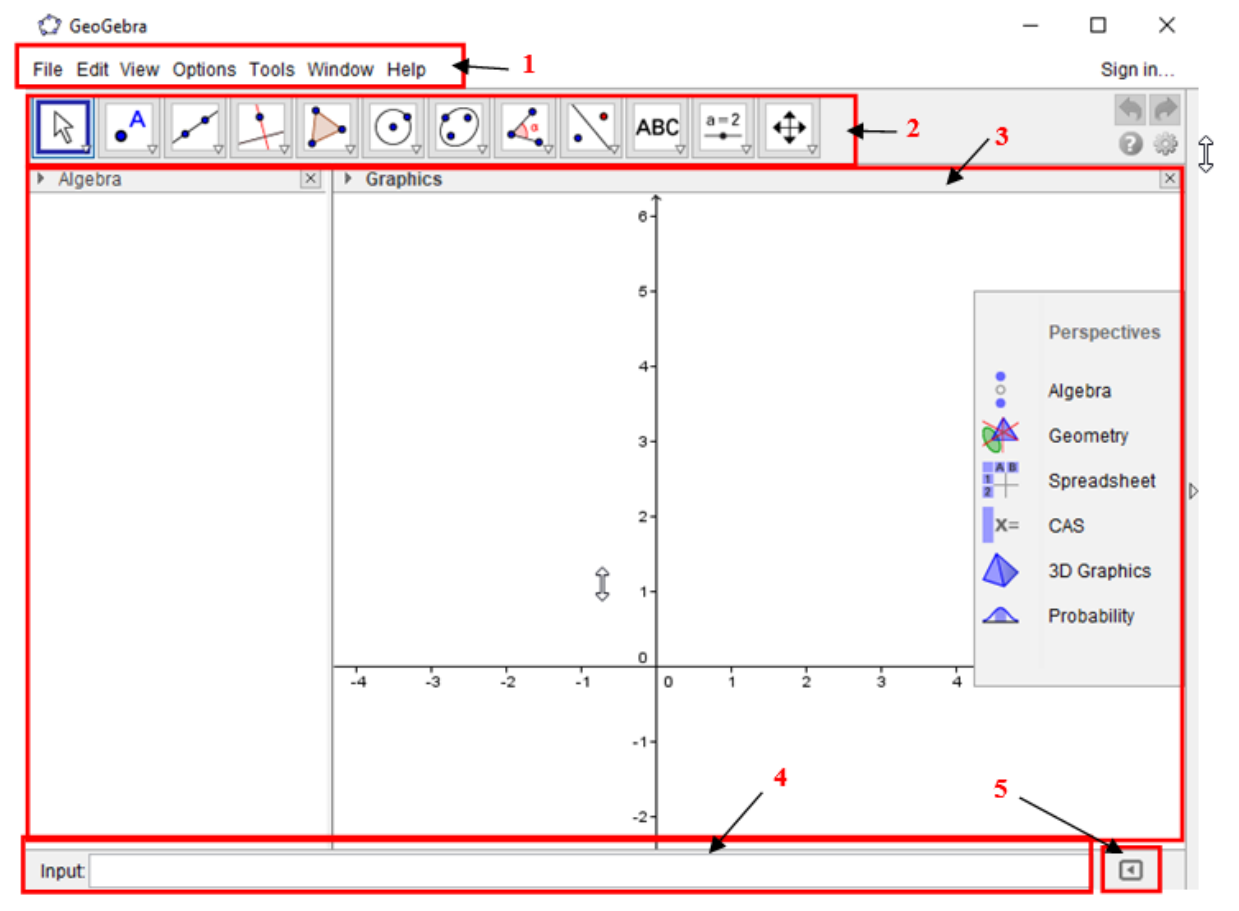

Gambar 3. Tampilan dan bagian-bagian GeoGebra

Bagian-bagian GeoGebra secara singkat dapat dijelaskan sebagai berikut. (1) Menu Bar, yang berisi menu-menu sebagaimana umumnya tampilan windows. Menu bar ini terdiri dari menu: file, edit, options, tools, window, help; (2) Tools Bar, berisi tool-tool untuk mengambar objek matematika, menuliskan teks, menggeser objek dan lain-lain; (3) Area kerja (Style Bar View), yang merupakan tempat kita bekerja di GeoGebra. GeoGebra memiliki beberapa Style Bar View, yaitu Style Bar Graphics View, Style Bar Geometry View, Style Bar Algebra View, Style Bar Spreadsheet View, Style Bar CAS View, Style Bar Probability View (4) Input Bar, merupakan fasilitas untuk menuliskan perintah-perintah dengan teks terkait objek yang akan dibuat/diatur.

GeoGebra mempunyai berbagai kelebihan, diantaranya: merupakan software open source, bersifat dinamis, memiliki fasilitas untuk memvisualisasikan atau mendemonstrasikan konsep-konsep matematika serta sebagai alat bantu untuk mengkonstruksi konsep-konsep matematika, mempunyai banyak resources yang dapat 
langsung digunakan, terdapat Classroom yang dapat dimanfaatkan untuk aktivitas pembelajaran interkatif secara online dimana aktivitas peserta dapat termonitor. Sifat dinamis GeoGebra menjadikan software ini dapat dijadikan pilihan untuk pembelajaran matematika yang interaktif, sehingga memberikan pengalaman pembelajaran tersendiri bagi peserta didik. Sumber belajar (resources) yang dimiliki GeoGebra yang siap digunakan mencapai lebih dari 1 juta, sebagaimana ditunjukkan pada gambar 4 . Hal ini tentu akan sangat membantu para guru dalam menyediakan media pembelajaran matematika yang diperlukan.

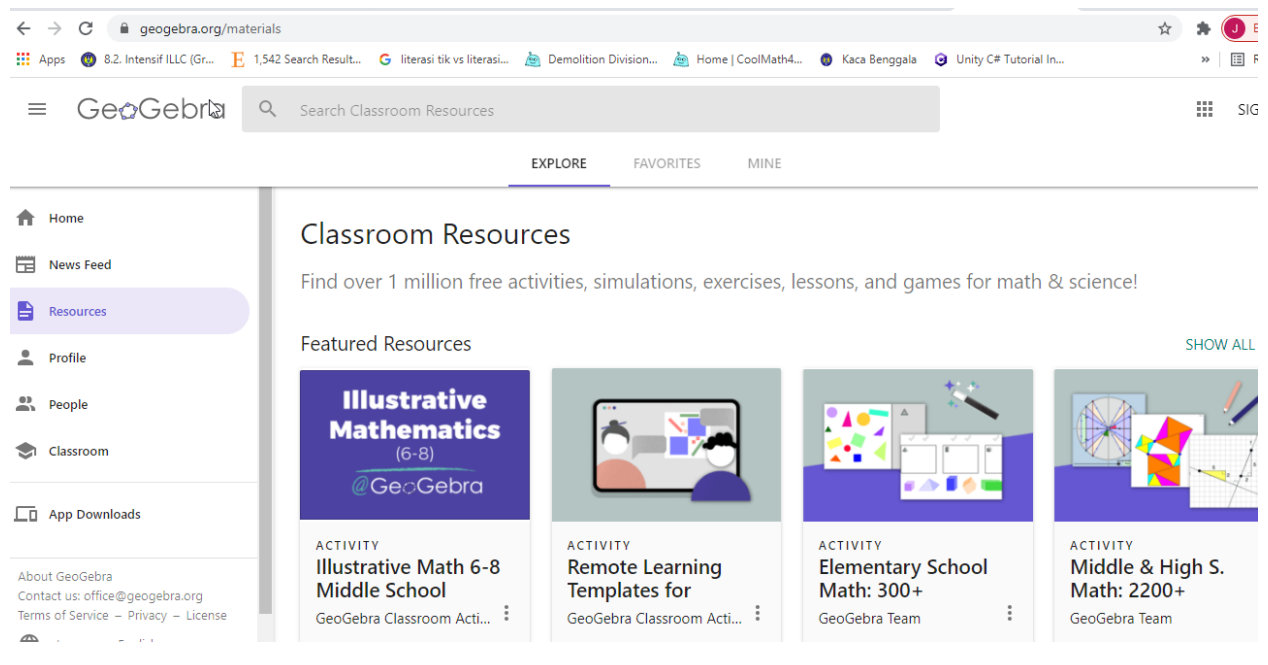

Gambar 4. Sumber belajar (Classroom Resources) di GeoGebra

Fitur lain yang belum lama disediakan oleh GeoGebra adalah GeoGebra Classroom. Fasilitas ini menambah keunggulan yang dimiliki oleh GeoGebra, dimana melalui fasilitas ini guru akan lebih mudah mengetahui aktivitas pembelajaran yang dilakukan oleh peserta didiknya. Di GeoGebra Classroom juga terdapat fasilitas whiteboard yang dapat digunakan untuk pembelajaran secara daring.

Kelebihan lain dari GeoGebra adalah kemudahan dalam hal membuat media pembelajaran matematika dibandingkan dengan menggunakan software lain. Hal ini sejalan dengan yang disampaikan oleh Hohenwarter dkk yang menyampaikan bahwa membuat materi di GeoGebra lebih mudah dan memakan waktu lebih sedikit dibandingkan dengan perangkat lunak lain. (Hohenwarter et al., 2007).

\subsection{Kebermanfaatan GeoGebra dalam pembelajaran matematika}

Berbagai kegiatan dapat dilakukan dengan memanfaatkan GeoGebra dalam pembelajaran matematika, dari yang sederhana sampai ke kompleks. Berikut diberikan beberapa contoh secara singkat pemanfaatan GeoGebra dalam pembelajaran matematika.

(1) Membelajarkan konsep garis sejajar dan garis tegak lurus, penggunaan GeoGebra pada pembelajaran ini dapat dilakukan dengan cara peserta didik diminta mengesergeser salah satu atau kedua garis yang sejajar dan juga garis yang tegak lurus. Dimana 
sebelumnya guru telah mengkonstruksi garis sejajar dan garis siku-siku yang akan digunakan dalam pembelajaran ini. Selanjutnya menggunakan Lembar Kerja Siswa (LKS) peserta diminta mengisi LKS terhadap kedudukan dari kedua garis tersebut, untuk selanjutnya diminta memberikan kesimpulan mengenai sifat-sifat garis sejajar maupun sifat-sifat garis tegak lurus.

(2) Membelajarkan konsep segitiga samakaki. Pembelajaran menggunakan GeoGebra dilakukan dengan cara peserta didik diminta mengeser-geser titik-titik sudut pada segitiga samakaki (Dimana sebelumnya guru telah mengkonstruksi segitiga samakaki). Selanjutnya peserta didik diminta mencatat pada LKS, besar masing-masing sudut dan panjang masing-masing sisi segitiga pada setiap perubahan titik sudut yang dilakukan, sehingga dihasilkan 5 atau lebih data besaran masing-masing titik sudut dan panjang masing-masing sisi segitiga. Peserta didik diminta memperhatikan 5 atau lebih besar masing-masing titik sudut dan panjang masing-masing sisi segitiga. Selanjutnya pesert didik diminta secara pribadi atau berkelompok menyimpulkan sifat-sifat dari segitiga samakaki. Hal ini dapat diterapkan juga untuk segitiga samasisi dan segitiga siku-siku.

(3) Mengkonstruksi segitiga samakaki. Siswa diminta mengkonstruksi segitiga samakaki menggunakan GeoGebra dengan berbagai cara, menggunakan pengetahuan tentang sifat-sifat segitiga samakaki yang telah dimiliki. Hal ini dilakukan ketika peserta didik telah diberi pengetahuan dan keterampilan dalam menggunakan GeoGebra. Kegiatan belajar ini diharapkan dapat mengkonstruksi pengetahuan peserta didik terhadap berbagai cara yang memungkinkan untuk mengkonstruksi segitiga samakaki sekaligus dapat menumbuhkan kreativitas.

(4) Konsep integral Riemann. Pembelajaran konsep integral Riemann digambarkan oleh Hohenwarter dkk berikut. Dalam membelajarkan konsep integral Riemann dapat dibuat media pembelajaran yang memuat grafik fungsi $f$, yang mempunyai titik a dan b dapat dipindahkan sepanjang sumbu x untuk memodifikasi interval yang diselidiki. Terdapat juga bilah geser (slider) $n$, peserta didik dapat mengubah jumlah persegi panjang yang digunakan untuk menghitung jumlah bawah dan atas dengan menggeser slider tersebut. Media pembelajaran tersebut sebagaimana ditunjukkan pada gambar 5. 


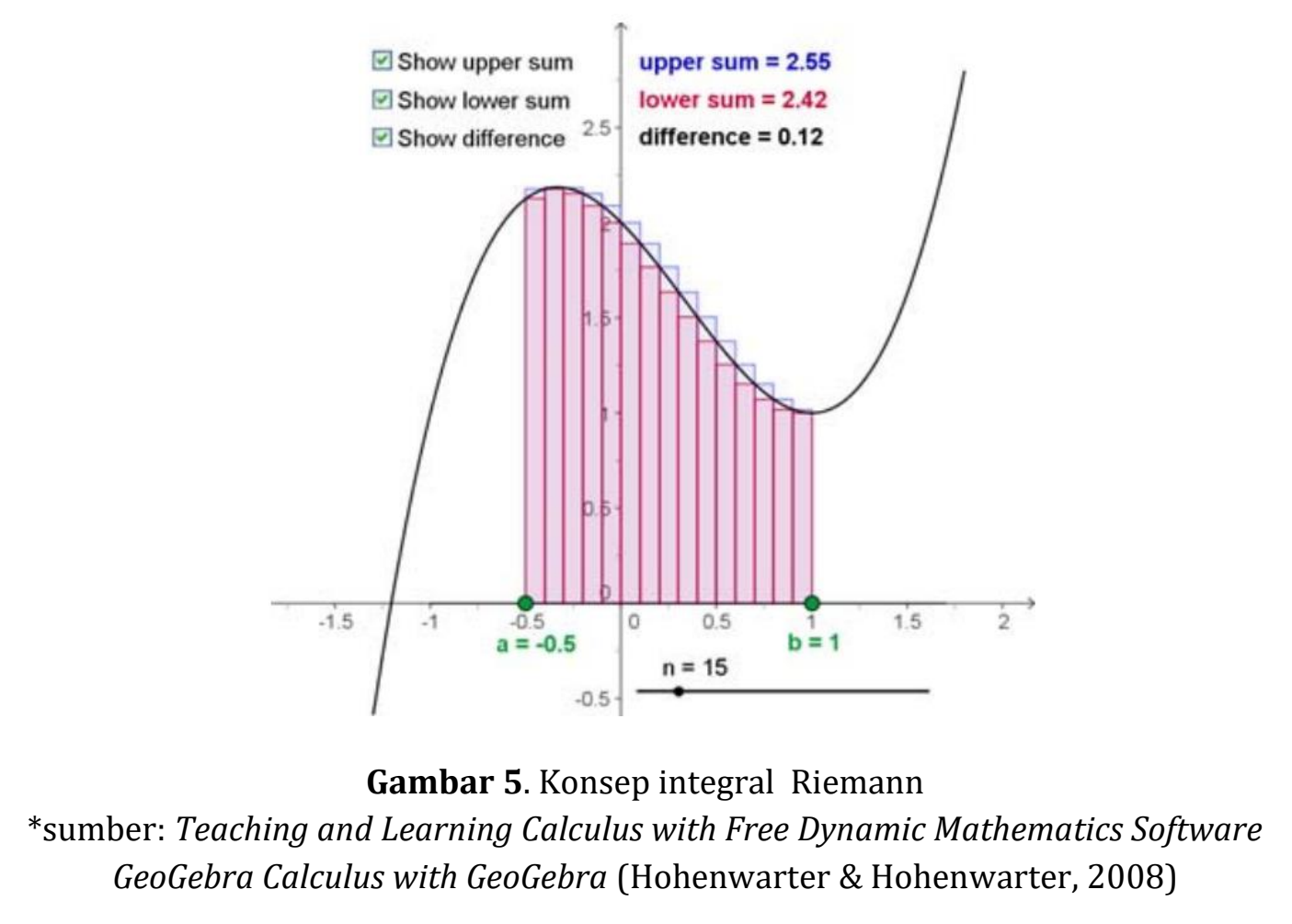

Peserta didik dapat mengeksplorasi berbagai aspek integral Riemann dengan dipandu oleh beberapa perintah, pertanyaan dan tugas berikut. (a) Anda dapat menggunakan bilah geser $n$ untuk mengetahui bagaimana persegi panjang untuk jumlah bawah / jumlah atas dibangun; (b) Berikan penjelasan, apa yang terjadi pada nilai dari jumlah bawah dan jumlah atas saat Anda meningkatkan jumlah persegi panjang?; (c) Bayangkan, seandainya slider $n$ panjangnya tak terhingga, dan memungkinkan Anda membuat rekam jejak dalam jumlah tak terhingga, apa yang terjadi dengan lebar sebuah persegi panjang jika $n$ menjadi tak terhingga; (d) Jelaskan apa yang akan terjadi dengan nilai-nilai jumlah bawah dan jumlah atas ketika Anda pindahkan $n$ sampai tak terhingga?

Hal-hal di atas memberikan wawasan tentang bagaimana memanfaatkan GeoGebra dalam pembelajaran matematika, dimana GeoGebra dapat dimanfaatkan untuk mendemonstrasikan atau memvisualisasikan konsep-konsep matematis, sebagai alat bantu untuk mengkonstruksi konsep-konsep matematis. Hal sesuai yang disampaikan oleh Mahmudi (2011) bahwa dengan beragam fasilitas yang dimiliki, GeoGebra dapat dimanfaatkan sebagai media pembelajaran matematika untuk mendemonstrasikan atau memvisualisasikan konsep-konsep matematis serta sebagai alat bantu untuk mengkonstruksi konsep-konsep matematika. Beberapa contoh lain pemanfaatan program GeoGebra dalam pembelajaran matematika disampaikan oleh Mahmudi sebagai berikut. a. Menghasilkan lukisan-lukisan geometri dengan cepat dan teliti dibandingkan dengan menggunakan pensil, penggaris, atau jangka. b. Adanya fasilitas animasi dan gerakan-gerakan manipulasi (dragging) pada program GeoGebra dapat memberikan pengalaman visual yang lebih jelas kepada siswa dalam memahami 
konsep geometri. c. Dapat dimanfaatkan sebagai balikan/evaluasi untuk memastikan bahwa lukisan yang telah dibuat benar. d. Mempermudah guru/siswa untuk menyelidiki atau menunjukkan sifat-sifat yang berlaku pada suatu objek geometri.

Berikut disampaikan beberapa penelitian yang mendukung terhadap kebermanfaatan penggunaan GeoGebra dalam pembelajaran matematika. Dalam proses pembelajaran matematika, penggunaan GeoGebra dapat mendukung kreativitas siswanya dan juga mendukung kolaborasi. Granberg \& Olsson (2015) menyampaikan bahwa GeoGebra mendukung kolaborasi dan penalaran kreatif dengan memberikan ruang kerja dan umpan balik bersama yang menjadi subjek bagi penalaran kreatif. Kegiatan kolaboratif siswa tersebut juga bertujuan untuk berbagi alasan satu sama lain dalam meningkatkan alasan kreatif mereka. Terkait penggunaan GeoGebra yang menumbuhkan kemampuan berpikir kreatif, juga disampaikan oleh Tikasari \& Kurniasih (2015) bahwa dalam beberapa model pembelajaran yang digunakan guru menggunakan GeoGebra, diantaranya model pembelajaran kooperatif dengan strategi Think-Talk-Write (TTW) berbantuan GeoGebra, dapat menumbuhkan kemampuan berpikir kreatif matematis siswa.

Selain mendukung penalaran kreatif dan kolaboratif, GeoGebra juga meningkatkan pemahaman konsep peserta didik, membuat siswa lebih terlibat dalam proses belajar, dan juga membuat pembelajaran lebih efektif. Hal ini terungkap dalam beberapa penelitan berikut. Pratiwi (2016) menyampaikan bahwa Geogebra memiliki pengaruh positif terhadap peningkatan kemampuan pemahaman konsep matematis dalam proses pembelajaran. Sementara Reis (2010) dan Minarto (2017) menyampaikan bahwa penggunaan GeoGebra dalam pembelajaran juga membuat siswa lebih terlibat dalam proses belajar dan berbagai indera ikut terlibat, sehingga tercapai keberhasilan yang lebih tinggi. Sejalan dengan hal tersebut (Reis, 2010) juga menyampaikan bahwa pemanfaatan Geogebra dalam pembelajaran matematika menjadi faktor penting sehingga pembelajaran menjadi efektif. Guru dapat membelajarkan siswa untuk belajar, bukan sekedar untuk menghafal. Hal lain yang juga masih sejalan dengan penelitian Reis dikemukan oleh Fitriasari (2017) bahwa pembelajaran pada grafik fungsi kuadrat dengan bantuan program GeoGebra lebih efektif dibanding pembelajaran konvensional. Sedangkan menurut Zengin dkk, GeoGebra dengan instruksi yang ada didalamnya sebagai pelengkap instruksi konstruktivis lebih efektif daripada metode pengajaran konstruktivis tanpa bantuan komputer. (Zengin et al., 2012). Penelitian lain yang juga mendukung bahwa penggunaan GeoGebra meningkatkan aktifitas disampaikan juga oleh Sihwidi (2016) yang menyatakan bahwa aplikasi Geogebra dapat meningkatkan aktifitas dan kompetensi materi tranformasi geometri bagi siswa kelas XI semester 3 program teknik komputer jaringan SMK Negeri 1 Tulang Bawang Tengah. Dari berbagai penelitian di atas terlihat dengan jelas bahwa penggunaan GeoGebra dalam proses pembelajaran mempunyai banyak manfaat. Berbagai manfaat tersebut diantaranya: mendukung kreativitas (menumbuhkan kemampuan berpikir kreatif), mendukung kolaborasi, meningkatkan pemahaman peserta didik terhadap konsep matematis, membuat siswa lebih terlibat dalam proses belajar, lebih banyak indera yang ikut terlibat dan juga membuat pembelajaran lebih efektif. 


\section{Kesimpulan}

GeoGebra memiliki berbagai fasilitas yang menunjang pembelajaran matematika. GeoGebra dapat digunakan untuk mendemonstrasikan atau memvisualisasikan konsep-konsep matematis serta sebagai alat bantu untuk mengkonstruksi konsepkonsep matematis. Penggunaan GeoGebra dalam pembelajaran matematika dapat menumbuhkan penalaran kreatif matematis, mendukung kolaborasi, membuat siswa lebih terlibat dalam proses belajar dan semakin banyak indera yang ikut terlibat dalam pembelajaran dan pembelajaran menjadi efektif. Penggunaan GeoGebra dapat mendukung dalam melatih cara berpikir dan bernalar serta menarik kesimpulan; mengembangkan kreativitas; mengembangkan kemampuan pemecahan masalah; dan mengembangkan kemampuan mengkomunikasikan gagasan, atau yang dikenal juga sebagai 4C.

Penggunaan GeoGebra menawarkan peluang guru dan peserta didik untuk menggunakannya baik di kelas maupun di rumah tanpa batas. GeoGebra menyediakan sumber belajar yang dapat diakses setiap saat, sehingga memudahkan guru dan peserta didik dalam pembelajaran matematika. GeoGebra juga menyediakan classroom yang memberikan fleksibilitas kepada peserta didik untuk mempelajari materi maupun mengerjakan tugas yang diberikan oleh gurunya diwaktu pembelajaran maupun diluar pembelajaran, dimana guru dapat mengecek aktivitas peserta didiknya di classroom tersebut.

\section{Daftar Pustaka}

Atikasari, G., \& Kurniasih, A. W. (2015). Keefektifan Model Pembelajaran Kooperatif Dengan Strategi Ttw Berbantuan Geogebra Terhadap Kemampuan Berpikir Kreatif Matematis Siswa Kelas Vii Materi Segitiga. Unnes Journal of Mathematics Education., 4(1). https://doi.org/10.15294/ujme.v4i1.7447

Baswedan, A. (2016). Peraturan Menteri Pendidikan dan Kebudayaan No. 22 tahun 2016 tentang Proses Standar Pendidikan Dasar dan Menengah. Peraturan Menteri Pendidikan Dan Kebudayaan, Jakarta, Kemdikbud.

Dikovic, L. (2009). Implementing dynamic mathematics resources with geogebra at the college level. International Journal of Emerging Technologies in Learning, 4(3), 51-54. https://doi.org/10.3991/ijet.v4i3.784

Fitriasari, P. (2017). Pemanfaatan Software Geogebra Dalam Pembelajaran Matematika. Jurnal Pendidikan Matematika RAFA, 3(1), 57-69.

Granberg, C., \& Olsson, J. (2015). ICT-supported problem solving and collaborative creative reasoning: Exploring linear functions using dynamic mathematics software. Journal of Mathematical Behavior, 37, 48-62. https://doi.org/10.1016/j.jmathb.2014.11.001.

Harini, L. P. I., \& I Gede Santi Astawa. (2015). PENINGKATAN KEMAMPUAN GURU DALAM MENGGUNAKAN GEOGEBRA SEBAGAI MEDIA PEMBELAJARAN MATEMATIKA SMP. Proceeding SNATIA.

Hohenwarter, M., \& Hohenwarter, J. (2008). Teaching and Learning Calculus with Free Dynamic Ma- thematics Software GeoGebra Calculus with GeoGebra. Proceedings of the International Conference on the Teaching of Mathematics - TSG 16, September 2016, 1-9.

Hohenwarter, M., Jarvis, D., \& Lavicza, Z. (2009). Linking Geometry, Algebra and Mathematics Teachers: GeoGebra Software and the Establishment of the International GeoGebra Institute. International Journal for Technology in Mathematics Education, 16(2), 83-87.

Hohenwarter, M., Preiner, J., \& Yi, T. (2007). Incorporating GeoGebra into Teaching Mathematics 
at the College Level. Proceedings of ICTCM, 68-70.

Koswara, U., W., T. Y., \& Rosita, N. T. (2017). Pelatihan Program Geogebra Bagi Guru Matematika Smp Di Kabupaten Sumedang. E-Dimas, 8(1), 77. https://doi.org/10.26877/edimas.v8i1.1376

Mahmudi, A. (2011). Pemanfaatan Geogebra dalam Pembelajaran Matematika. Seminar Nasional Matematika Dan Pendidikan Matematika, 10-19.

Minarto. (2017). PENGGUNAAN APLIKASI GEOGEBRA SEBAGAI MEDIA PEMBELAJARAN DALAM UPAYA MENINGKATKAN PRESTASI BELAJAR MATEMATIKA PADA MATERI FUNGSI KUADRAT Oleh Minarto SMA Negeri 1 Bangorejo E-mail : minarto.boy@gmail.com ABSTRAK. E-Jurnal Mitra Pendidikan, 1(3), 1-10. http://www.ejurnalmitrapendidikan.com/index.php/e-jmp/article/download/52/24/

NCTM. (2000). Six Principles for School Mathematics. National Council of Teachers of Mathematics,

$1-6$. http://www.nctm.org/uploadedFiles/Math_Standards/12752_exec_pssm.pdf

Padmanthara, S. (2004). Pembelajaran berbantuan komputer (PBK) dan manfaat sebagai media pembelajaran. Tekno, 1, 1693-8739.

Pratiwi, D. D. (2016). Pembelajaran Learning Cycle 5e berbantuan GeoGebra terhadap Kemampuan Pemahaman Konsep Matematis. Al-Jabar: Jurnal Pendidikan Matematika, 7(9), 191-202. https://doi.org/10.1017/CB09781107415324.004

Rahmawati, N. I. (2018). Pemanfaatan ICT dalam Meningkatkan Kemampuan Literasi Matematika. Prisma, 1, 381-387. https://journal.unnes.ac.id/sju/index.php/prisma/article/view/19606/9529

Reis, Z. A. (2010). Computer supported mathematics with Geogebra. Procedia - Social and Behavioral Sciences, 9, 1449-1455. https://doi.org/10.1016/j.sbspro.2010.12.348

Sholihah, D. A., \& Mahmudi, A. (2015). Kefektifan Experiential Learning Pembelajaran Matematika MTs Materi Bangun Ruang Sisi Datar. Jurnal Riset Pendidikan Matematika, 2(2), 175. https://doi.org/10.21831/jrpm.v2i2.7332

Sihwidi, J. (2016). Penggunaan Geogebra untuk Meningkatkan Aktivitas dan Penguasaan Kompetensi Transformasi Geometri di SMKN 1 Tulang Bawang Tengah. Indonesian Digital Journal of Mathematics and Education, 3(4), 208-220.

Sumaryanta, \& Wibawa, A. D. (2020). REKONSTRUKSI PEMBELAJARAN MATEMATIKA DI ERA REVOLUSI INDUSTRI 4.0. Indonesian Digital Journal of Mathematics and Education, 7(1), $11-25$.

http://p4tkmatematika.kemdikbud.go.id/journals/index.php/idealmathedu/article/view $/ 135 / 34$

Supianti, I. I. (2018). Pemanfataan Teknologi Informasi dan Komunikasi (TIK) dalam Pembelajaran Matematika. MENDIDIK: Jurnal Kajian Pendidikan Dan Pengajaran, 4(1), 6370. https://doi.org/10.30653/003.201841.44

Wardhani, S. (2010). Implikasi Karakteristik Matematika dalam Pencapaian Tujuan Mata Pelajaran Matematika di SMP/MTs. DIKLAT Guru Pemadu/Guru Inti/Pengembang Matematika SMP Jenjang Dasar.

Zengin, Y., Furkan, H., \& Kutluca, T. (2012). The effect of dynamic mathematics software geogebra on student achievement in teaching of trigonometry. Procedia - Social and Behavioral Sciences, 31(2011), 183-187. https://doi.org/10.1016/j.sbspro.2011.12.038. 